\title{
An Immediate Solution for the Euro Area Crisis: \\ A Grand European Investment Plan
}

Pompeo Della Posta, Enrico Marelli e Marcello Signorelli

\begin{abstract}
After the double crisis that hurt the Eurozone (with the two recessions in 2008-09 and 201213), the financial situation has improved, especially thanks to the battery of unconventional measures undertaken by the European central bank. However, even in the recovery period, real economic growth has been weak and uneven in the euro area; above all, the general economic and social situation is still unsatisfactory. In some peripheral Eurozone countries, the fall in aggregate demand and the collapse of investment (especially public investment) are far from being recovered.

A possible solution is therefore - waiting for the reforms needed for the "completion" of the European monetary union - the realization of a Grand European Investment Plan, along the lines proposed by Marelli and Signorelli (2017a) and by Della Posta et al. (2018). This plan can stimulate both current and medium term GDP growth; moreover, it can contribute to the stabilization of both public debt as a ratio of GDP and interest rates. It might even help in the restoration of a proEuropean sentiment, which lately has been fading away because of the growth-depressing fiscal austerity policies followed in many euro area countries and the consequent dreadful social conditions.
\end{abstract}

Keywords: euro, European Union, Eurozone crisis, fiscal policy, investment plan JEL: E65, F36, H54, N14 


\section{Introduction}

In Europe, we are approaching the $20^{\text {th }}$ anniversary of monetary union. It was the $1^{\text {st }}$ of January 1999 and, at that time, there were many hopes that the process of integration could continue toward a genuine European Economic and Monetary Union (EMU) and, in perspective, also a political union. The initial benefits of the euro were indeed significant for many countries especially in terms of interest rate reductions. Unfortunately, a financial crisis erupted in the world economy reaching a climax ten years ago (September 2008) with the default of Lehman Brothers. The following Great Recession (2008-09) and the euro area crisis (2010-13) have been so hard that some peripheral countries of the Eurozone encountered major difficulties in returning to a normal growth path, with great economic, social and even political consequences. As a matter of fact, especially thanks to the battery of unconventional measures undertaken by the European central bank, the financial situation has generally improved; but real economic growth has been weak and uneven in the euro area; the general economic and social situation is still distressing in some countries. The long stagnation in some Eurozone's countries has also been caused by wrong or delayed policies by the EU institutions.

As a consequence, some crucial reforms in the EU governance and institutions as well as radical changes in the economic policies are necessary to complete the monetary union and to achieve a "genuine" economic union. The problem is the lack of political consensus for radical reforms and the fact that, in any case, such reforms would take a long time to be implemented; in the meanwhile, the Eurozone (or even the EU) might disintegrate, for economic or political reasons. This is why we propose the realization of a Grand European Investment Plan, along the lines suggested by Marelli and Signorelli (2017a) and by Della Posta et al. (2018). This plan can stimulate both current and medium term GDP growth; as a result, it can contribute to the stabilization of both public debt to GDP ratio and interest rates. It might even help in the restoration of a pro-European sentiment, which lately has been fading away because of the wrong policies adopted so far.

The structure of this paper is as follows. In Section 2, we overview the key features of the long crisis that hurt the Eurozone over the last decade, by emphasizing the limits of the current Eurozone governance and the adopted policies. Section 3, after reviewing the future scenarios hypothesised by the EU institutions, discusses the most important reforms needed to guarantee the survival of the euro in the long-run. Section 4 presents our proposal for a Grand European Investment Plan. Section 5 discusses the possible indirect effects on the sentiment of European people and the feasibility of further steps toward European integration. Section 6 concludes.

\section{The legacy of the long crisis in the Eurozone}


In the first decade after the introduction of the euro, the monetary union was considered as irreversible, not only by the policymakers but also by the markets. Once the devaluation risk disappeared, the very perceived low default risk, even in peripheral countries, warranted almost identical interest rates on the bonds issued by all Eurozone countries. This in turn helped keeping public deficits low and supporting economic growth. Monetary stability kept the inflation rate low everywhere in the area and caused the appreciation of the euro vis-à-vis other currencies (including the US dollar); this strength had, however, indirect effects on the current accounts of the Eurozone's peripheral countries.

Then, a global financial crisis started in the US. ${ }^{1}$ The climax was reached in September 2008, when Lehman Brothers, a financial services company specializing in investment banking operating since the mid-nineteenth century, declared bankruptcy. The Wall Street stock exchange collapsed and panic spread to all world stock exchanges. It is a bit paradoxical that this event, which occurred in the United States of America, had the most detrimental and lasting consequences on this side of the Atlantic, particularly in some euro area countries.

Bank failures and default of other financial corporations proliferated and contagion spread to the global financial system, with a sharp deterioration of expectations and degree of trust. Then, the financial crisis soon became, through several channels, a real economy crisis. So, in 2008-09 the socalled "Great Recession" followed: production, income, investment, trade and other real variables suffered a collapse of an entity never seen in the world economy since the Great Depression of the 1930s.

Afterwards, the world economy, including the United States, had an almost continuous recovery since 2010 . This recovery was favoured by the expansionary monetary and fiscal policies undertaken by most developed countries (notice that China, India and other emerging economies had only a mild deceleration in 2009). Monetary policy immediately became more expansionary, with drastic cuts in interest rates operated by the major central banks as early as Autumn 2008 (the ECB also did so, but more slowly). The effectiveness of the expansionary measures, after having reached the "zero-interest rate policy" (ZIRP), was increased by the adoption of unconventional measures, such as quantitative easing (QE), soon implemented by the US Fed (led by Ben Bernanke), the Bank of Japan and the Bank of England. It consisted in the purchase of public and also private securities, with the aim of providing liquidity to the system and supporting the financial conditions of the credit institutions. Thus, central banks' budgets began to expand rapidly in 200914, with the partial exception of the ECB.

Besides the accommodative monetary policy and numerous bank bailouts, also fiscal policies were extremely expansionary in most countries of the world, by allowing the full operation

\footnotetext{
${ }^{1}$ For a more complete account, see Marelli and Signorelli (2017a), among others.
} 
of the automatic stabilizers and the adoption of additional fiscal stimulus packages (for example the package decided by President Obama in 2009, worth 800 billion dollars) (see Della Posta, 2017). Public budget deficits reached 10 per cent of GDPp in some countries for a short period. Of course, countries with relatively low levels of public debt generally had higher margins to implement such counter-cyclical fiscal policies. In the EU, instead, the fiscal rules prevented such expansionary policies (as we shall discuss below).

The Eurozone, in fact, was hurt by a second recession in 2012-13, due to the notorious "sovereign debt crisis" (Table 1). After the "Greece case" exploded in 2009-10 (originally caused by a cheating on the figures of the public deficit), there was a collapse of confidence in the financial markets, contagion propagated to the countries in the Eurozone periphery, whose bonds suffered because of increasing "spreads" with respect to the interest paid on German "bunds". The financial situation deteriorated both because in the Eurozone appropriate crisis-management tools were lacking (the "save-State" funds ${ }^{2}$ were introduced in 2010-11, but they were limited in size) and also as a consequence of the early decision on the "private sector involvement", that excluded the complete bail out of sovereign bonds (after the Merkel-Sarkozy's declaration, in Autumn 2010).

The high spreads reached top values in the so-called PIIGS ${ }^{3}$ (Portugal, Ireland, Italy, Greece, Spain) in 2011-12; then they started to decrease after the summer of 2012 (see Figure 1). The PIIGS were the peripheral countries of the euro area most affected by the sovereign debt crisis. Despite different initial conditions in the public vs. private imbalances, they generally suffered because of gaps in competitiveness (relative to Germany) and - in most cases - deficits in the current accounts of the balance of payment. The high interest rates on sovereign bonds originated from the perception of two types of risks affecting their sovereign debt: i) the default risk inherent to the presumed inability of a given country to repay its own debt on maturity, ii) the risk connected to a change in the currency of repayment (currency redenomination risk). In fact, for the first time since the introduction of the euro (1999), the markets were beginning to question the irreversibility of the common currency, because of the possibility of exit of individual countries or even the disintegration of the monetary union. The contagion in the euro area was caused by both the financial international integration (e.g. French and German banks holding sovereign bonds of the PIIGS) and the interconnection between public and private debt: a great part of the sovereign bonds are in the hands of private banks that, when a crisis happens, should be bailed out by the States (this is the so-called "doom loop").

\footnotetext{
${ }^{2}$ That is the temporary European Financial Stability Facility and the permanent European Stability Mechanism. Notice however that big countries like Italy or also Spain would be, in any case, both too big to bail out (because of the limited size of the mentioned funds) and too big to default (their failure would almost certainly cause a systemic crisis and the likely collapse of the euro).

${ }^{3}$ The acronym was first used by English media, sometimes with the aim of accusing the lax and spendthrift behavior of Southern countries and with implicit denigratory intentions. This is the reason why Della Posta (2018b) explicitly avoids adopting it and uses instead the expression "euro area crisis countries".
} 
Fig. 1 - Long term interest rates (January 2007 - May 2018)

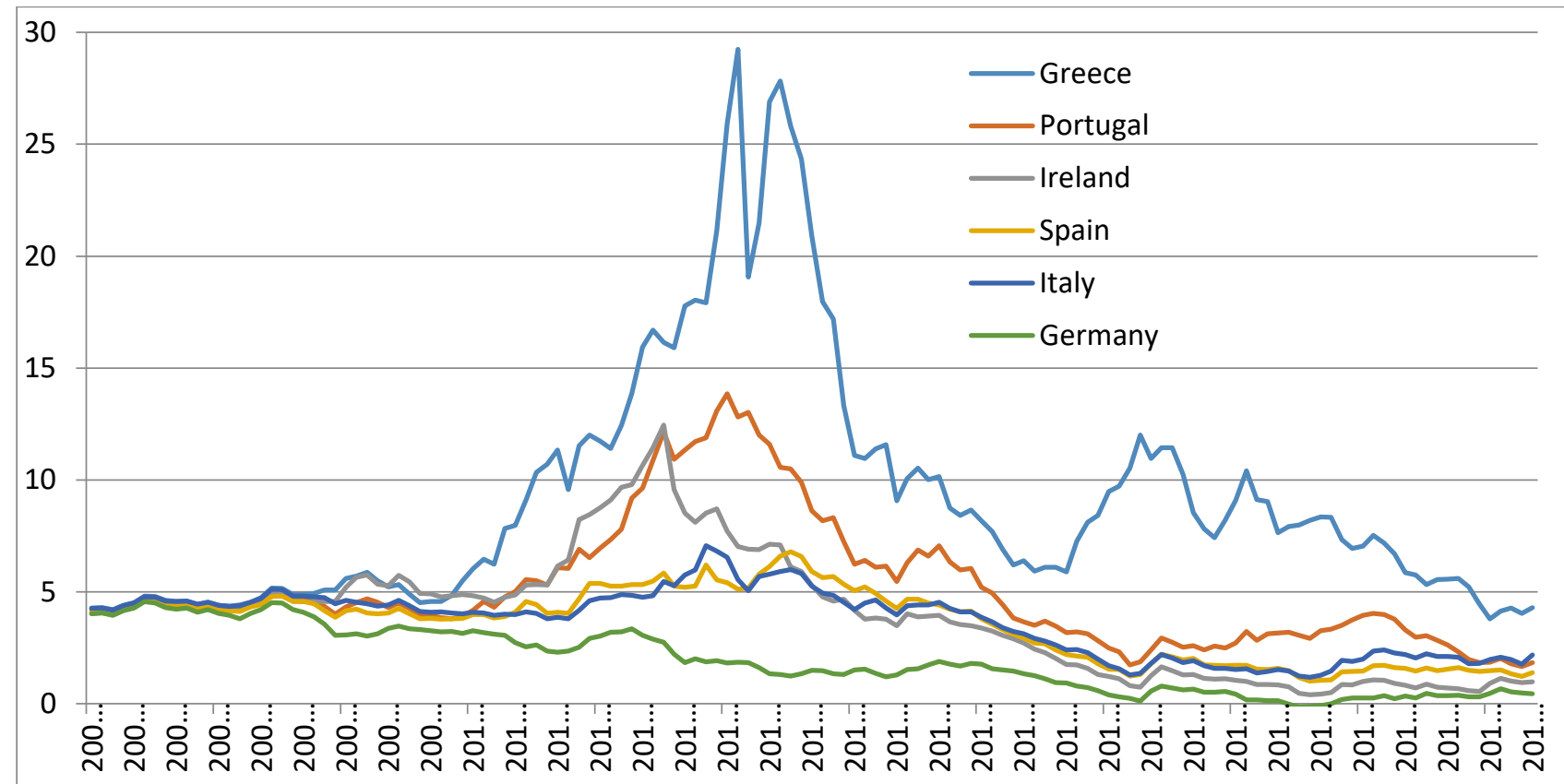

Source: Eurostat (long term interest rates as convergence criteria in the Maastricht Treaty) Note: monthly data on annual base.

The "spread crisis" had a short duration. The explanation is to be found not so much in the financial assistance provided by the EU institutions (the mentioned "save state funds"), that provided help through the involvement of the so-called "troika" (European Commission, European Central Bank, International Monetary Fund), requiring macroeconomic adjustment and fiscal consolidation of the assisted countries. The key reason is, instead, provided by the new ECB's strategy - consisting in both credible announcements and new monetary policies - that began with the presidency of Mario Draghi. In particular, after his announcement made in July 2012 "we shall save the euro, whatever it takes", the Outright Monetary Transactions (OMT) plan ${ }^{4}$ was launched in September 2012, providing unlimited support to the most vulnerable countries, with the specific aim of reducing the spreads on sovereign bonds. Although never implemented, it succeeded (see previous Figure 1). Thus, Draghi was able, despite the opposition of German representatives in the ECB board, to overcome in an indirect way one of the institutional shortcomings of the ECB, i.e. not being a "lender of last resort" for the States (see De Grauwe, 2013).

In any case, the double recession and subsequent faint recovery (since 2013) in the Eurozone were aggravated by the uncertain, delayed and inadequate economic policies followed by the EU institutions (see also Marelli and Signorelli, 2017a). While the original financial imbalances were

\footnotetext{
${ }^{4}$ The previous Securities Market Program (SMP), adopted in 2010-11, was more limited in size, duration and it was targeted to specific countries.
} 
in the private sector of the economy ${ }^{5}$ and public accounts deteriorated because of the recession, the EU institutions considered the public deficits and debts as the key cause of the imbalances. By reversing the causality link, the EU institutions interpreted the rise in public deficits and debts as the main cause of the crisis, while it was the most evident consequence. In fact, the original financial imbalances were, also in Europe, in the private sector, with very high private debt over GDP ratios (in the United Kingdom, Ireland, Spain, etc.) and many private banks (in Germany, France, etc.) exposed to the debts of peripheral countries. In this situation, during crisis periods, sudden capital outflows may happen, causing imbalances in the Eurozone's payment system (Acocella, 2016, Beker and Moro, 2016).

Thus an "austerity" approach was imposed to all Eurozone countries, through a new, more rigid Stability and Growth Pact and then by the Fiscal Compact, requiring a balanced budget in the medium term. Such restrictive policies aggravated the recession or weakened the recovery, as shown in Table $1^{6}$ (see also Blyth, 2015, Holland, 2016).

Table 1 - GDP growth rate in selected countries (2007-18)

\begin{tabular}{|l|c|c|c|c|c|c|c|c|c|c|c|c|}
\hline & 2007 & 2008 & 2009 & 2010 & 2011 & 2012 & 2013 & 2014 & 2015 & 2016 & 2017 & $2018^{*}$ \\
\hline Italy & 1.5 & -1.1 & -5.5 & 1.7 & 0.6 & -2.8 & -1.7 & 0.1 & 1.0 & 0.9 & 1.5 & 1.5 \\
\hline Germany & 3.3 & 1.1 & -5.6 & 4.1 & 3.7 & 0.5 & 0.5 & 1.9 & 1.7 & 1.9 & 2.2 & 2.3 \\
\hline France & 2.4 & 0.2 & -2.9 & 2.0 & 2.1 & 0.2 & 0.6 & 0.9 & 1.1 & 1.2 & 1.8 & 2.0 \\
\hline Spain & 3.8 & 1.1 & -3.6 & 0.0 & -1.0 & -2.9 & -1.7 & 1.4 & 3.4 & 3.3 & 3.1 & 2.9 \\
\hline Greece & 3.3 & -0.3 & -4.3 & -5.5 & -9.1 & -7.3 & -3.2 & 0.7 & -0.3 & -0.2 & 1.4 & 1.9 \\
\hline Ireland & 3.8 & -4.4 & -4.6 & 2.0 & 0.0 & -1.1 & 1.6 & 8.3 & 25.6 & 5.1 & 7.8 & 5.7 \\
\hline Portugal & 2.5 & 0.2 & -3.0 & 1.9 & -1.8 & -4.0 & -1.1 & 0.9 & 1.8 & 1.6 & 2.7 & 2.3 \\
\hline Eurozone-19 & 3.0 & 0.4 & $\mathbf{- 4 . 5}$ & 2.1 & 1.5 & $\mathbf{- 0 . 9}$ & $\mathbf{- 0 . 2}$ & 1.3 & 2.1 & 1.8 & 2.4 & 2.3 \\
\hline U. K. & 2.6 & -0.6 & -4.3 & 1.9 & 1.5 & 1.3 & 2.1 & 3.1 & 2.3 & 1.9 & 1.8 & 1.5 \\
\hline Poland & 7.0 & 4.2 & 2.8 & 3.6 & 5.0 & 1.6 & 1.4 & 3.3 & 3.8 & 3.0 & 4.6 & 4.3 \\
\hline EU-28 & 3.1 & 0.4 & -4.4 & 2.1 & 1.7 & -0.5 & 0.3 & 1.8 & 2.3 & 2.0 & 2.4 & 2.3 \\
\hline U.S. & 1.8 & $\mathbf{- 0 . 3}$ & $\mathbf{- 2 . 8}$ & 2.5 & 1.6 & 2.2 & 1.7 & 2.6 & 2.9 & 1.5 & 2.3 & 2.9 \\
\hline Japan & 1.7 & -1.1 & -5.4 & 4.2 & -0.1 & 1.5 & 2.0 & 0.4 & 1.4 & 0.9 & 1.7 & 1.3 \\
\hline
\end{tabular}

Source: European Commission, European Economic Forecasts, Spring 2018; * forecasts.

Public accounts improved after 2010, with decreasing deficit/GDP ratios (while the debt/GDP ratios continued to rise for some more years). Notice, however, that it is extremely difficult, on economic and social grounds, to increase primary balances - as occurred in some euro

\footnotetext{
5 This was most evident in the case of Ireland, Portugal, Spain (besides the UK), where in 2007, before the financial crisis, the private debt was from 3 to 7 times the GDP (while in Greece and Italy, the two countries with the highest public debt, such ratios were between 1 and 2). In the former countries, in the new century there was, before the crisis, a sort of "drugged" growth, caused by low real interest rates, investment booms (especially in constructions), favorable credit conditions and burgeoning foreign direct investments. As a consequence the "sovereign debt crisis" should be better renamed "euro area crisis".

${ }^{6}$ The countries considered in the table are the three major Eurozone countries and the economies hit by the sovereign debt crisis; in addition, the two major EU countries outside the euro area: the United Kingdom and Poland; finally, the two largest non-European countries with a market economy: USA and Japan. For comparative reasons, the average values of the entire Eurozone (at 19) and the EU (at 28) are also shown.
} 
area countries - during recessions or slow economic recoveries, since at least the automatic stabilizers should be allowed to act. ${ }^{7}$

As noticed by Krugman (2010), the austerity approach was self-defeating, because it partly lowered public deficits, but the negative impact on GDP has been so large that it reduced the denominator of the debt/GDP ratios more than the numerator. This happened in a period when, in addition to a negative or very small real GDP growth, also inflation was close to zero (particularly in the 2014-16 period), thus making the fiscal adjustment more difficult. The negative impact of restrictive policies was also underestimated because of the wrong assessments of fiscal multipliers that, differently from what believed until 2010, were greater than one, especially during recessions, with zero interest rates and when many countries consolidate at the same time (see Blanchard and Leigh, 2013). In any case, the typical Keynesian effects of restrictive fiscal policies emerged, contrary to the "non-keynesian effects" and the so-called "expansionary austerity" (assumed in neoliberal approaches).

We must admit that within the Eurozone there were considerable cross-country differences in the impact of the crisis. The most dramatic and enduring cases refer to Greece and Italy, where the levels of production and income are still, in 2018, significantly below the pre-crisis levels (2007-08). On the opposite side, Germany and some other leading countries, recovered quickly and fully after the 2009 recession. In the middle, Ireland, Spain and more recently Portugal - although greatly damaged by the double recession - had satisfactory recoveries after 2014. However, also in the latter countries, the recession could have been less deep and social pain less dreadful had fiscal policy been more accomodative.

In fact, the social impact has been profound also in the latter countries and the unemployment rate, for instance in Spain, is still much higher compared to pre-crisis levels (Table 2). The dramatic effects in the labour markets especially concerned young people: youth unemployment greatly increased and has been persistent (Marelli and Signorelli, 2017c). Poverty or the risk of social exclusion still concerns more than 120 million people in Europe: it is in this area that we observe the greatest failure in reaching the objectives of the "Europe 2020" plan (see Eurostat, 2017). The rising inequalities, also driven by an unregulated globalization processes (Fadda and Tridico, 2017), led to a growing opposition, manifested not always in social conflicts, but rather in political movements supporting populist or nationalist approaches.

Table 2 - Total unemployment rate in selected countries (2007-18)

\begin{tabular}{|l|c|c|c|c|c|c|c|c|c|c|c|c|}
\hline & 2007 & 2008 & 2009 & 2010 & 2011 & 2012 & 2013 & 2014 & 2015 & 2016 & 2017 & $2018^{*}$ \\
\hline Italy & 6.1 & 6.7 & 7.7 & 8.4 & 8.4 & 10.7 & 12.1 & 12.7 & 11.9 & 11.7 & 11.2 & 10.8 \\
\hline
\end{tabular}

\footnotetext{
${ }^{7}$ Contrary to the recent Eurozone's experience, high GDP growth might well be a solution to the debt sustainability
} problems (see Della Posta, 2018a for a deeper analysis of the role played by GDP growth in the euro area crisis). 


\begin{tabular}{|l|c|c|c|c|c|c|c|c|c|c|c|c|}
\hline Germany & 8.5 & 7.4 & 7.6 & 7.0 & 5.8 & 5.4 & 5.2 & 5.0 & 4.6 & 4.1 & 3.8 & 3.6 \\
\hline France & 8.0 & 7.4 & 9.1 & 9.3 & 9.2 & 9.8 & 10.3 & 10.3 & 10.4 & 10.1 & 9.4 & 8.9 \\
\hline Spain & 8.2 & 11.3 & 17.9 & 19.9 & 21.4 & 24.8 & 26.1 & 24.5 & 22.1 & 19.6 & 17.2 & 15.3 \\
\hline Greece & 8.4 & 7.8 & 9.6 & 12.7 & 17.9 & 24.5 & 27.5 & 26.5 & 24.9 & 23.6 & 21.5 & 20.1 \\
\hline Ireland & 5.0 & 6.8 & 12.7 & 14.6 & 15.4 & 15.5 & 13.8 & 11.9 & 10.0 & 8.4 & 6.7 & 5.4 \\
\hline Portugal & 9.1 & 8.8 & 10.7 & 12.0 & 12.9 & 15.8 & 16.4 & 14.1 & 12.6 & 11.2 & 9.0 & 7.7 \\
\hline Eurozone-19 & 7.5 & 7.6 & 9.6 & 10.2 & 10.2 & 11.4 & 12.0 & 11.6 & 10.9 & 10.0 & 9.1 & 8.4 \\
\hline U. K. & 5.3 & 5.6 & 7.6 & 7.8 & 8.1 & 7.9 & 7.5 & 6.1 & 5.3 & 4.8 & 4.4 & 4.4 \\
\hline Poland & 9.6 & 7.1 & 8.1 & 9.7 & 9.7 & 10.1 & 10.3 & 9.0 & 7.5 & 6.2 & 4.9 & 4.1 \\
\hline EU-28 & 7.2 & 7.0 & 9.0 & 9.6 & 9.7 & 10.5 & 10.9 & 10.2 & 9.4 & 8.6 & 7.6 & 7.1 \\
\hline U.S. & 4.6 & 5.8 & 9.3 & 9.6 & 8.9 & 8.1 & 7.4 & 6.2 & 5.3 & 4.9 & 4.4 & 4.0 \\
\hline Japan & 3.8 & 4.0 & 5.1 & 5.0 & 4.6 & 4.3 & 4.0 & 3.6 & 3.4 & 3.1 & 2.8 & 2.8 \\
\hline
\end{tabular}

Source: Eurostat. * European Economic Forecasts, Spring 2018.

The Eurozone recovery has been favoured, on the whole, by the recent monetary policy followed by the European Central Bank (ECB). After the mentioned OMT plan, that was crucial to reduce the spreads on sovereign bonds and to "save the euro", and in addition to the ZIRP policy ${ }^{8}$ followed since 2014-15, the QE was activated in 2015, with the specific aim to raise the inflation rate. ${ }^{9}$ The initial impact of the QE was to cause a depreciation of the euro against foreign currencies (especially in the initial months of 2015), thus helping the economic recovery, but the inflation rate remained significantly below the ECB target (below but close to 2\%), at least until 2018.

In any case, the current account situation of most Eurozone peripheral economies improved in the recent period, despite persisting imbalances (also caused by the huge German surplus). ${ }^{10}$ Paradoxically, excluding 2009, in more recent years it was not external demand that caused the unsatisfactory economic growth in peripheral countries. Soon after the sovereign debt crisis, many countries adopted "internal devaluations", i.e. cutting wages (at least in the public sector) or halting wage increases, thus achieving indirectly gains in international competitiveness, at the cost of deteriorating social conditions and further compressing consumption and aggregate demand. Of course, it would be much better to increase competitiveness by enhancing productivity growth (rather than cutting wages), but this requires more investments, innovations, appropriate industrial policies, etc. (see below). In any case, rather than exports, internal demand was squeezed in the crisis period: public expenditure (because of the austerity), consumption (as a consequence of falls

\footnotetext{
${ }^{8}$ The Main Refinancing Operation (MRO) rate reached exactly 0 per cent in 2016; the rate on overnight deposits, negative since 2014, reached the lowest level $(-0,40 \%)$.

${ }^{9}$ It consisted in purchases, on the secondary market, of public and private bonds, worth 60 billion euro each month for the whole Eurozone; it was augmented to 80 billion/month from March 2016 to March 2017, then reduced to 30 billions from January 2018; and to 15 billion euro from October to December 2018, then it will cease.

${ }^{10}$ As an alternative to a generalised fiscal stimulus, as suggested also by Eichengreen (2012), Germany should play the role of "engine of Europe" (similarly to the USA, that have been the engine of the world in the past, thereby accepting to experience large current account deficits). As a matter of fact, the crisis has also been aggravated by a lack of macroeconomic coordination: tight austerity has been especially imposed on debtor (Southern) countries, while creditor (Northern) countries continued to follow balanced-budget policies, with huge trade surpluses in the case of Germany (see De Grauwe, 2013, Heise, 2015).
} 
in employment and/or wages), and especially investment. Total investment has shrunk in the whole Eurozone, but more deeply (by about one third) in the peripheral countries (the PIIGS) in the crisis period.

The pro-cyclical effect of the Eurozone fiscal rules caused also the collapse of public investment, especially in the years 2010-14 (Table 3). Notice that the so-called "Golden rule", i.e. the exclusion of investment expenditure from the computation of public deficits (for the SGP rules), has never been accepted. Notice that investments can sustain, in the short run, aggregate demand and employment; in the long run, they strengthen productive capacity, potential output and productivity.

Table 3 - Public investment (as \% of GDP) in selected countries (2007-18)

\begin{tabular}{|l|c|c|c|c|c|c|c|c|c|c|c|c|}
\hline & 2007 & 2008 & 2009 & 2010 & 2011 & 2012 & 2013 & 2014 & 2015 & 2016 & 2017 & $2018^{*}$ \\
\hline Italy & 2.9 & 3.0 & 3.4 & 2.9 & 2.8 & 2.6 & 2.4 & 2.3 & 2.2 & 2.1 & 2.0 & 2.0 \\
\hline Germany & 1.9 & 2.1 & 2.4 & 2.3 & 2.3 & 2.2 & 2.1 & 2.1 & 2.1 & 2.1 & 2.2 & 2.2 \\
\hline France & 3.9 & 3.9 & 4.3 & 4.1 & 4.0 & 4.1 & 4.0 & 3.7 & 3.4 & 3.4 & 3.4 & 3.4 \\
\hline Spain & 4.7 & 4.6 & 5.1 & 4.7 & 3.7 & 2.5 & 2.2 & 2.1 & 2.5 & 1.9 & 2.0 & 2.2 \\
\hline Greece & 4.9 & 5.6 & 5.7 & 3.7 & 2.5 & 2.5 & 3.4 & 3.7 & 3.9 & 3.5 & 4.6 & 4.0 \\
\hline Ireland & 4.6 & 5.2 & 3.7 & 3.3 & 2.4 & 2.0 & 2.0 & 2.1 & 1.7 & 1.8 & 1.9 & 2.1 \\
\hline Portugal & 3.2 & 3.7 & 4.1 & 5.3 & 3.5 & 2.5 & 2.2 & 2.0 & 2.2 & 1.5 & 1.8 & 2.2 \\
\hline Eurozone-19 & 3.2 & 3.3 & $\mathbf{3 . 6}$ & $\mathbf{3 . 4}$ & $\mathbf{3 . 1}$ & $\mathbf{2 . 9}$ & $\mathbf{2 . 8}$ & $\mathbf{2 . 7}$ & $\mathbf{2 . 7}$ & $\mathbf{2 . 6}$ & 2.6 & 2.6 \\
\hline U. K. & 2.5 & 3.0 & 3.3 & 3.2 & 3.0 & 2.8 & 2.6 & 2.8 & 2.7 & 2.7 & 2.6 & 2.6 \\
\hline Poland & 4.5 & 4.8 & 5.0 & 5.6 & 5.8 & 4.7 & 4.1 & 4.5 & 4.4 & 3.3 & 3.7 & 4.4 \\
\hline EU-28 & 3.2 & 3.4 & 3.7 & 3.5 & 3.3 & 3.1 & 2.9 & 2.9 & 2.9 & 2.7 & 2.7 & 2.8 \\
\hline U.S. & 3.8 & 4.0 & 4.2 & 4.1 & 3.9 & 3.6 & 3.3 & 3.2 & 3.2 & 3.1 & 3.2 & 3.2 \\
\hline Japan & 3.6 & 3.5 & 3.9 & 3.7 & 3.6 & 3.6 & 3.9 & 3.9 & 3.7 & 3.6 & 3.7 & 3.6 \\
\hline
\end{tabular}

Source: Eurostat (government gross fixed capital formation). * European Economic Forecasts, Spring 2018.

For achieving higher economic growth, structural reforms are repeatedly advocated by international institutions, including the EU. It is true that liberalisations or introducing more competition in some sectors (certain services, professional activities, credit sector), where it is lacking, can help. But structural reforms should not necessarily imply large reductions in taxation, if this leads to a cut in fundamental social services, expenditures for health or education, incentives to research and development: expenditures that in the crisis period have been already unduly cut and in some countries are extremely low. Instead, the lessening of fiscal pressure should be made possible by contrasting all forms of fiscal evasion and elusion. In addition, in order to raise production and productivity on the supply side, structural reforms should be complemented by a new industrial policy, innovations, R\&D, and more investments (see Cappellin et al., 2017).

Thus, in our opinion, there has been too much emphasis, by the EU institutions and policymakers, on structural reforms compared to aggregate demand management. Apart from the evidence that structural reforms have a positive impact on potential output only in the long run, data 
show that output gaps have been negative for a long period in the Eurozone; in countries like Italy, they have been negative over the whole decade since $2008 .{ }^{11}$ This is a clear indication of a lack of aggregate demand. Thus, expansionary stabilization policies are still needed. As mentioned above, monetary policy has progressively become more accommodative, but the drawback is that such policy is not able to solve, on its own, the stabilization problems, as admitted by Draghi himself (ECB, 2014). Moreover, the favourable conditions are reaching an end: the QE is going to stop at the end of 2018, interest rates will be raised in a short time ${ }^{12}$ and nobody knows what kind of monetary policy will be followed after the conclusion of Draghi's term (October 2019), but it will be likely that Germany will force a more conservative strand.

\section{The Future of the Eurozone according to European Institutions and the needed reforms for the euro's survival}

Since its introduction in 1999, the euro was considered as irreversible by the institutions and also by the markets. The exchange rates between the previous currencies and the new monetary unit were fixed "for ever": this was the final stage of the process leading to the European Economic and Monetary Union. More recently, following the sovereign debt crisis, because a redenomination risk made its appearance, many unconventional measures were introduced by the ECB (as illustrated in the previous section). ECB President, Mario Draghi, very often stressed the "irrevocability of the euro", although he also recognized the need to improve the functioning of the Eurozone. Without significant reforms euro's survival is not guaranteed: this is the opinion of many economists and policymakers. Some proposals have been made by the EU institutions themselves, in particular the EU Commission and the EU Council.

The 2012 (June 26) "Four presidents' report: Toward a Genuine Economic and Monetary Union" was the first official document of the EU institutions, after the beginning of the financial crisis, setting the need to realise a "stronger EMU architecture, based on integrated frameworks for the financial sector, for budgetary matters and for economic policy. All these elements should be buttressed by strengthened democratic legitimacy and accountability". The key limitation of this report is the fact that it was too short, generic and, when talking about "the next decade", was nonspecific concerning the time horizon. It was followed by the 2015 (June 22) "Five presidents' report: Completing Europe's Economic and Monetary Union" that has the merit to further focus on the Eurozone; it concluded that "the foundations of EMU need to be strengthened to ensure a

\footnotetext{
11 Moreover, the methodology used by the EU Commission to estimate output gaps tends to underestimate the magnitude of the economic cycle by assuming pronounced hysteresis effects. This procedure produces wrong policy implications by attaching too much importance to structural policies with respect to aggregate demand management; in addition, it entails too high structural deficits, thus requiring an excessive budgetary adjustment.

${ }^{12}$ Following the international markets: in the US they already reached 2\%, after three years of increases. In June 2018 , however, Draghi announced that they will remain at the current (zero) level at least until September 2019.
} 
smooth functioning of the currency union and to allow the member states to be better prepared for adjusting to global challenges". The final aim indicated in the report is to reach by 2025 " $a$ deep and genuine EMU" and it mainly argued - without a complete definition of all the necessary operative details - on the possible progress on the following four fronts: (i) economic union (focusing on convergence, prosperity, and social cohesion), (ii) financial union (completing the banking union and launching the capital markets union), (iii) fiscal union (ensuring sound and integrated fiscal policies), and (iv) democratic accountability, legitimacy and institutional strengthening (reviewing the political construction of the EMU).

The 2017 (March) European Commission "White Paper on the Future of Europe" does not specifically focus on the Eurozone but on the EU-27 perspectives (after Brexit) and it presents five different scenarios on how Europe could evolve by 2025. The scenarios are described generically, without providing any details of the institutional processes. Here we briefly mention the different scenarios only summarizing the key implications. Scenario 1 "Carrying on": (i) incremental progress on improving the functioning of the euro area; (ii) budget innovations to reflect the reform agenda agreed at 27; (iii) new decision-making process (that however remains difficult to grasp and whose capacity to deliver does not always match expectations). Scenario 2 "Nothing but the single market": (i) cooperation in the euro area remains limited; (ii) budget will be refocused to finance essential functions needed for the single market; (iii) decision-making may be easier to understand but capacity to act collectively is still limited (hence issues of common concern often will need to be solved bilaterally). Scenario 3 "Those who want more do more": (i) as in "Carrying on" except for a group of countries who will deepen cooperation in areas such as taxation and social standards; (ii) as in "Carrying on", additional budgets are made available by some Member States for the areas where they decide to do more; (iii) as in "Carrying on", a positive agenda for action at 27 yields positive results (some groups achieve more together in certain domains but decision-making becomes more complex). Scenario 4 "Doing less more efficiently": (i) several steps are taken to consolidate the euro area and ensure its stability; the EU27 does less in some parts of employment and social policy; (ii) budget significantly redesigned to fit the new priorities agreed at the level of the EU27; (iii) initial agreement on tasks to prioritise (once in place, decision-making may be easier to understand and the EU may act quicker and more decisively where it has a greater role). Scenario 5 "Doing much more together": (i) economic, financial and fiscal Union is achieved as envisioned in the report of the Five Presidents of June 2015; (ii) significantly modernised and increased budget, backed up by own resources (a euro area fiscal stabilisation function can be introduced); (iii) decision-making is faster and enforcement is stronger across the board; but questions of accountability arise for some who feel that the EU has taken too much power away from the 
Member States. In short, this last scenario is the only one that - although in general terms - includes some indications on how to improve the functioning of the Eurozone and its resilience to crises.

The 2017 White Paper has been followed by additional European Commission "Reflection Papers", including one on the "Deepening the Economic and Monetary Union, on the basis of the Five Presidents' Report of June 2015". This "Reflection Paper"13 (May 2017) has the great merit for the first time by an European institution - to finally design possible detailed reforms of the Eurozone in order to improve its functioning; however, some proposals - contained in the third and fourth part of the document - are weak and some key issues are still lacking. ${ }^{14} \mathrm{We}$ recall, however, that in the "Reflection Paper" there are some specific proposals to make the Eurozone more resilient to future shocks, in particular two options for introducing a "stabilisation function": the European Investment Protection Scheme and the European Unemployment Reinsurance. However, in our view, such schemes could effectively work only with adequate resources of a specific Eurozone budget. In addition, the 2025 deadline is too far away for contrasting the current economic and social situation still hampering some countries (like Italy and Greece). As for the Financial Union, looking beyond the Banking Union and the Capital Markets Union, the "sovereign bond-backed securities" proposal seems just an ingenious (although second best) solution, alternative to the Eurobonds proposal, for which the political consensus is still lacking. Finally, the Commission's paper also contains some ideas for improving the European democracy and governance, although the final goal of a "political union" is not clearly defined.

Finally, it should be stressed that in the most recent Euro Summits (December 2017, March and June 2018) only minor reform steps were defined and the main point (the creation of a fiscal capacity at the Eurozone level) will be probably discussed in the next Summit, in December 2018.

As a final comment on the official documents, we can observe that the European institutions look quite aware of the need to reform the Eurozone, but the concrete definition of the process is still lacking, especially due to the persistently missing political consensus in the Member states. Yet, a "status quo" scenario bears many risks: the Eurozone will probably survive in the short/medium-run, especially without new financial crises or the political decision of individual big countries to exit, but without some radical reforms the long-run sustainability of the euro will not be guaranteed,.

Many reforms proposals have been extensively discussed in the recent literature. ${ }^{15} \mathrm{~A}$ first wise reform is the adoption of an adequate Eurozone budget, that could be used also for both stabilization and crisis management purposes, including a European unemployment insurance

\footnotetext{
${ }^{13}$ European Commission (2017), Reflection Paper on the Deepening of the Economic and Monetary Union.

${ }^{14}$ See Marelli and Signorelli (2017c) for more details.

${ }^{15}$ On the topic of how to complete EMU, see Baldwin e Giavazzi (2015); Baldwin e Giavazzi (2016); Bénassy-Quéré and Giavazzi (2017); Minenna (2016); Costa Cabral et al. (2017). For a more complete discussion see Marelli and Signorelli (2017a), in particular the references provided in Chap. 7.
} 
scheme. In some proposals, certain fiscal policy decisions should be centralised with the establishment of a EU Finance Minister. For example, within the discussion of more general reforms of the EU (and Eurozone) governance, some proposals have been made for a Ministry of Finance of the Eurozone (supported also by the French President, Emmanuel Macron) or a new European Treasury, or also a "European Fiscal Institute" (that could be an evolution of the European Stability Mechanism) (see among others Bénassy-Quéré and Giavazzi, 2017 and European Commission, 2017b). ${ }^{16}$ However, in our opinion (as already discussed), such institutional reforms will only guarantee the euro survival in the long run if two conditions will be satisfied: (i) the Eurozone budget should have an adequate size; (ii) the EU Finance Minister should not only supervise national public accounts (deficits and debts), but should have the power to dispose of sufficient resources (and allocate them where needed), both for stabilisation purposes and also to support economic convergence among member States.

In more general terms, for EMU long-run sustainability one principle should be accepted: risk-reduction should be accompanied by risk-sharing. This includes a progressive mutualisation of public debts, through the issue of Eurobonds in substitution (at least partly) of national bonds. This reform has not, at present, the necessary political consensus. However, while the entire mutualisation of public debt will be almost impossible also in the long-run, a more realistic and possible solution is a partial (up to $60 \%$ of GDP of each country) transformation of national debts in Eurobonds (see for more details Marelli and Signorelli, 2017a). Some intermediate proposals have also been made, such as the "European safe bonds", that are formed from the senior tranche of a diversified portfolio of euro area sovereign bonds, but do not imply any risk sharing ${ }^{17}$, since a common warranty only applies to the new bonds issued at the European level (see Brunnermeier et al. 2016, Pagano, 2017).

Some other important reforms to be implemented in order to make possible the long-run survival of the euro are related to monetary policy. While EU institutions themselves are aware of the needed steps in the short-run to complete the banking union ${ }^{18}$, and while there are some fears about the direction of monetary policy after the conclusion of Draghi's Presidency (October 2019), there has been a debate among scholars about the need to achieve in the future a more complete mandate for the ECB, including for instance also targets on real variables (employment and growth). It is difficult that consensus will gather on this proposal, both currently and in the future;

\footnotetext{
${ }^{16}$ See also the critiques in Marelli and Signorelli (2017c) on the "Reflection paper" (European Commission, 2017b).

17 This is also a drawback of the proposed instrument, since as Minenna (2017) puts it: "The lack of risk-sharing therefore leaves the door open for spreads to widen again in times of stress". A limited moral hazard is instead implied by the PADRE (Politically Acceptable Debt Restructuring in the Eurozone) plan (see Paris and Wyplosz, 2014).

${ }^{18}$ The third pillar of the banking union, i.e. a common insurance scheme of bank deposits, is still missing. Again, the requests of Germany and Northern European countries to substantially reduce the non-performing loans and also the weight of domestic debt in the budget of private banks reveals the priority given to risk-reduction compared to risksharing; those requests should be adequately contrasted.
} 
however it is clear that the ECB should formally ${ }^{19}$ dispose of all the instruments of other central banks, including the "lender of last resource" function to guarantee the Eurozone debt. ${ }^{20}$

We are aware that it is unrealistic to believe that the most radical reforms will be introduced and implemented over the next few years, also because - besides the lack of political consensus in most EMU countries - doing that would imply the need to change the existing Treaties. However, it is really crucial that the entire process be well defined and progressively implemented, including a final long-run perspective of political integration in a federal system, that should be well designed in order to guarantee democratic participation, decision and control.

We turn now to the reforms that can be realized in a short-run horizon. A first reform regards the fiscal rules on public deficit and debt; as a matter of fact, the Stability and Growth Pact might be changed without complex institutional reforms. Specifically, there is a need to adopt more growth-friendly fiscal rules, in order to favour a higher GDP growth, in particular through an increase of public investment ${ }^{21}$. As already emphasized (Section 2), public investment significantly declined in the past decade in several Eurozone countries, especially those more hit by the long crisis. This cut has been the worst economic policy mistake, also because public investment indirectly affects private investment (that also shrunk during the crises) and aggregate demand in general; moreover, public investment supports, in a long-run perspective, also aggregate supply, potential output and productivity.

The most simple way to make an increase of public investment possible is the adoption of a "golden rule", i.e. the exclusion of national public investment from the count of deficit relevant for the application of the excessive deficit procedure (in the Stability and Growth Pact). However, this proposal - in order to be accepted by Germany and other Northern European countries - needs more details: (i) the medium term objective of zero (overall) deficit should be transformed in a continuous objective of "zero or positive" (net of investment) balance on annual public accounts, with a limit of an overall deficit lower than $3 \%$ of $\mathrm{GDP}^{22}$; (ii) in order to favour the selection of high quality public investment able to favour effective and potential economic growth, all countries should introduce ex ante, in itinere and ex post controls on the investment plans; (iii) with the aim to guarantee the sustainability of public debts, the continuous decreasing tendency of the debt to GDP ratio should be confirmed for the countries with a ratio higher than $60 \%{ }^{23}$

\footnotetext{
${ }^{19}$ Beyond the unconventional measures envisaged by President Draghi, such as the OMT plan and the QE.

${ }^{20}$ According to Pisani-Ferry (2012) to make the euro less vulnerable, it is appropriate to eliminate at least one condition of the following "trinity": the prohibition of monetary financing of deficits, the lack of co-responsibility on sovereign debts and the interdependence between banks and debts sovereign.

21 De Grauwe e Ji (2016), Micossi (2016) and De Grauwe (2017b) are some of the many authors attributing a key role to public investment.

${ }^{22}$ Only in well defined big shock situations, causing a recession, a higher deficit should be permitted.

${ }^{23}$ The decreasing direction has to be compulsory, however the speed of this tendency should be negotiated also taking into account the cyclical conditions.
} 
An alternative possible reform, better on several aspects than the one just illustrated but still attributing a special role to public investment, could be realised through a direct Eurozone initiative, as illustrated in the next section.

\section{An immediate solution: a Grand European Investment Plan}

While waiting for the more general, but difficult, reforms of the euro architecture, that should try to make the monetary union more complete (including the introduction of a significant Eurozone budget), we think that macroeconomic policy should be quickly made more expansionary, by means of a European large investment plan, possibly financed by Eurobonds.

The idea of a Grand European Investment Plan arose from the consideration of the large impact of the long crisis. As already illustrated (see Section 2), the real problems in the Eurozone concerned internal demand: consumption and, even more significantly, investment (together with public expenditure because of the mentioned austerity). Over the crisis period, total investment collapsed by about one third in the peripheral countries of the Eurozone, and they are still much lower than the 2008 levels. What is unjustifiable is that even public investment has been deeply cut, thereby exacerbating the pro-cyclical behaviour of fiscal policies.

The Juncker plan introduced in 2015 was an initial sensible response, but it has been too timid as for the resources allocated and too slow in its implementation. It is hard to believe that the current very favourable monetary conditions - zero interest rates (or around $2 \%$ interest rate on the long term sovereign debt of peripheral countries) - do not allow policymakers to find investment projects whose rate of return exceeds the cost of financing (see also Micossi, 2016, De Grauwe, 2017). We do not necessarily refer here to huge infrastructure projects or public works (including transports, communications, digital agenda), that are often characterized by long planning and implementation times as well as by budgets continuously revised upward. We rather mean a variety of "micro-investments" spread over the territory (see Cappellin et al. 2017), such as: environment protection, safeguard of the territory, anti-seismic interventions, energy efficiency, social housing, hospitals and schools building and renovation, local transport, tourist infrastructures, and many other "micro-investments"; specific investments in education and R\&D could also be included.

Marelli and Signorelli (2017a) originally proposed a plan of new investments additional to the current national ones, worth about 500 billion euros, i.e. equivalent to 5\% of Eurozone's GDP, to be realized within three years (with a possible extension to five years). It could be financed either by Eurobonds ${ }^{24}$ or through a major involvement of the European Investment Bank, that might issue bonds to be purchased either by the market or, on the secondary market, by the ECB itself (such purchases have been partially made within the QE program). The direct involvement of the EU

\footnotetext{
${ }^{24}$ For instance, eurobonds at 10 years could be issued at a low interest rate (probably lower than $2 \%$ ).
} 
budget is at present not possible because of its limited size, although the principle has been accepted even by the European Commission. ${ }^{25}$

Notice that a positive shock on public investment can have a double economic benefit, as already stressed. In the short run, it supports aggregate demand, production and employment; through multiplier and expectation effects, it stimulates also private investment and consumption. A second economic benefit can be obtained in the long run, since it raises productive capacities, potential output and productivity ${ }^{26}$; thus, it will be self-financed, thanks to the increase of future incomes and tax receipts.

In order to favour the necessary political consensus on this proposal from Germany and other "core" countries, the resources should be distributed to each Eurozone country in proportion to the national population (or GDP) and also the annual interest rate expenditure should be added to each national budget with the same distribution (i.e., proportionally to the population or GDP). The debt service could be limited, given the current low interest rates; we can assume it, in a precautionary way, to be around $2 \%$ on 20 -years maturity bonds, equivalent to 10 billion euros for the whole Eurozone. ${ }^{27}$

This idea has been better defined in Della Posta et al. (2018), where a "market-financed and growth-enhancing investment plan for the euro area" has been proposed. In that paper, it is shown, through a theoretical model, that the investment plan will not only improve the economic and social situation, but it will make more sustainable also the national sovereign debts. These positive effects are derived thanks to the improved growth prospects and the interest rates reduction. In particular, the plan will relax the constraint on the primary surplus that would be necessary to guarantee the public debt stability of individual countries, thereby reducing the risk premium and exerting a further stabilizing effect on the interest rate.

It is important to stress that the proposed plan would not imply any direct commitment of euro area (or EU) countries to rescue high indebted countries. It would just mean to create the conditions for some growth enhancing and interest rate reducing policies that would also indirectly favor the reduction of the high national public debts. The investment projects will be monitored by euro area

\footnotetext{
${ }^{25}$ See the Document "A Stabilization Function" within the Roadmap set in December 2017 (European Commission, 2017a): the proposed "European Investment Protection Scheme" could get, in this proposal, some limited annually budgeted grant support from the EU budget; this budget can also provide some guarantees for issuing loans to provide the stabilisation function. The principle to stabilize investments over time and to protect them (including infrastructure and skills development) in the event of large asymmetric shocks is suitable, but the hypothesised procedure is cumbersome and probably ineffective.

${ }^{26}$ According to De Grauwe and Ji (2016), an investment plan has a greater growth impact compared to structural reforms.

${ }^{27}$ A more specific example could be helpful: Italy, that represents $17.5 \%$ of Eurozone's economy (this is the weight in ECB's capital), should pay 1.75 billion euro of interests each year, in front of 87.5 billion euro of new investments (to be realized within 3 years).
} 
(or EU) countries, so the solidarity mechanism that such a plan implies would only be limited to this new level of euro area debt that would be under the direct control of all stakeholders.

A possible operative solution is the establishment of an external institution centered around the European Commission, through which "core" and Northern euro area countries would supervise the market-financed investment operations. Northern euro area countries, then, should realize that the umbrella provided by the euro area would be a costless way for them to keep enjoying a still significant part of the gains that they have been making so far (especially in terms of the positive net exports and current accounts).

\section{An additional, relevant, political benefit of a Grand European Investment plan}

The proposed investment plan is much more extensive compared to the Juncker plan (introduced in 2015) and, also, innovative in the financing solutions. It is consistent with previous EU programs, such as the Lisbon agenda and "Europe 2020", where a smart, sustainable and inclusive growth is the key goal; such programs, however, did not provide specific resources at the European level to reach the stated objectives. As anticipated in Section 2, a large expansionary plan will improve not only economic growth but also the social conditions in the European countries.

This point brings us to discuss the crucial relationship between markets and democracy (somebody may refer instead to the relationship between markets and populism), or to the old issue of the business political cycle, that would need to be further scrutinized. As a matter of fact, the conclusion of that literature was that the search for consensus determined a worsening of public finances and it provided therefore a quite relevant argument for concluding that the fiscal authority had to be limited in its ability to act.

That representation of politics is, however, not necessarily the only one that can be made. In our case, we can observe that the fiscal austerity has discouraged euro-enthusiasts and has made far less appealing, to many European citizens, the perspective of proceeding further in the process of European integration. Not only fiscal austerity did not succeed in reducing the public debt-to-GDP ratios across Europe (because of the perverse effect it had on GDP, as we have argued above and as it is widely recognized in the literature). It had a possibly even worse effect which needs to be considered, namely the disaffection towards Europe of a large share of (mainly Southern) European citizens.

So, turning to an expansionary, market-financed investment plan, will have a positive effect not only on GDP growth, on interest rates and on public debt-to-GDP ratios, but also - and maybe even more importantly - on the perspectives themselves of the long run success of EMU and potentially of the EU. 
It could be argued that while this would gain the favor and the consensus of Southern euro area countries, the opposite would be true for the citizens of Northern euro area countries. Those citizens, though, should be reminded that the true choice to be made may not between a situation in which countries remain in the euro area accepting a big investment plan or not accepting it, but rather between the former and no euro area at all, since over time no countries will desire to remain in a union which imposes more costs than the benefits they receive from it.

What precedes takes us also to discuss the position that Dani Rodrik (2018) and Joseph Stiglitz (2017) have on populism. It has been quite often argued that financial markets oblige governments to take restrictive fiscal and monetary positions: in the light of the risk of the emergence of populism, the need to obtain democratic consensus may lead to opposite conclusions. In other words, there may well be a divergence between the requirements of market orthodoxy and those of a democratic consensus. Notice that populist movements have already influenced political decisions in many EU countries (in some of them they are already represented in the national government). ${ }^{28}$

The presence of a sort of "fiscal lender of last resort" - ready to provide the fiscal expansion that is necessary to obtain a democratic consensus - might be necessary, then, precisely to reassure the markets. The presence of such a guarantee, however, does not necessarily mean that it will need to be exerted, as the ECB's OMT and the experience of the ESM clearly show.

This means, then, that markets and democracy may well go along, rather than conflicting with each other. The democratic support of the euro area is a necessary ingredient for the success of the process of monetary, economic and political integration. ${ }^{29}$ The causation link might actually be reversed, then: the need to obtain the democratic consensus and to avoid populism might well suggest the adoption of appropriate euro area expansionary investment policies. This would help gaining the favor of the markets, precisely because they would recognize that such non-restrictive policies are necessary to plant the seeds for the future euro area GDP growth and success.

\section{Concluding remarks}

In this paper, we have seen that the euro, a new currency introduced in 1999, has witnessed two completely different periods. In the first decade it warranted stability in the Eurozone (also in world markets it was considered a valid alternative to the dollar). In the second decade of its life, after the global financial crisis, it exhibited its weaknesses. In our opinion, the limits are not so much of the new currency itself, but rather of the incompleteness of the monetary union and of the

\footnotetext{
${ }^{28}$ The risk of new political equilibria in the European Parliament, after the 2019 elections, are also large.

29 The delicate equilibrium between democracy and populism emerges also in Rodrik's trilemma (Global Markets, National control, Democracy): in order to regain national sovereignty and democracy, the global dimension (or EU's) may well have to be abandoned. So, if Southern countries feel that their national control is lost, they may want to regain it and leave the EU: Brexit can be interpreted along these lines (see for example Della Posta and Rehman, 2017).
} 
wrong economic policies adopted after the sovereign debt crisis. The key mistakes, in particular the austerity approach imposed on peripheral countries in a recession period, have been discussed in Section 2. Only thanks to the progressively accommodative monetary policy by the ECB, the euro managed to survive so far.

Looking at future scenarios, the official documents by the EU institutions are aware of the need to complete the monetary union (Section 3), but the list of necessary reforms is rather vague and the time span too long and uncertain. In the long-run the Eurozone's might collapse without the necessary reforms (see also Stiglitz, 2016).

The key reforms, according to us, for the survival of the euro (illustrated in section 3), include a monetary policy with a wider mandate and a specific Eurozone budget, both as an effective crisis-management tool and for stabilisation purposes. A new central authority responsible for the fiscal policy (a European Fiscal minister or similar) should dispose of adequate resources, both for macroeconomic stabilisation (possibly including unemployment insurance) and to support real convergence across the economies of the monetary union. Of course we are aware that, due to the need to create the necessary political consensus, the mentioned reforms constitute a long-run program, to be realised little by little with a policy of "small steps" (e.g., De Grauwe and Ji, 2016). In our opinion, the essential thing is that the direction of movement should be very clear and that the steps, even if "small", should be constantly realized over time. Otherwise the risk is to remain for some years in a substantial "status quo", finally leading - in the long-run - to the collapse of the monetary union and perhaps of the EU itself.

It is even more urgent to change macroeconomic policies to support aggregate demand, in particular through public investments, either at the national level (introducing a greater margin of intervention thanks to a "golden rule" in the Growth and Stability Pact) or at the European level, or both. A Grand European Investment Plan, to be realized by the issue of Eurobonds, would be the best solution (see Section 4). We have emphasized the stabilizing effects of such an investment plan, that would increase GDP growth and reduce interest rates on existing national public debts; through this channel, it would also improve the financial conditions in the Eurozone. The plan will not only increase GDP growth, both in the short-run (aggregate demand stimulus) and in the longrun (supply-side effects), but - by gradually improving the social situation - will also lessen the opposition toward the European integration process, making possible further reforms in the governance of the European monetary union and thus making more feasible the survival of the euro.

\section{References}


Acocella, N. "Signalling imbalances in the EMU”, in: Dallago B; Guri G.; McGowan J. (eds.) A Global Perspective on the European Economic Crisis, London, Routledge, 2016.

Baldwin, R.; Giavazzi, F. (eds.) The Eurozone crisis: A consensus view of the causes and a few possible solutions, VoxEU eBook, London, CEPR Press, 2015.

Baldwin, R.; Giavazzi, F. (eds.) How to fix Europe's monetary union: Views of leading economists, VoxEU eBook, London, CEPR Press, 2016.

Beker, V.; Moro, B. (eds.) The European Crisis, Bristol, World Economic Association Books Conference Series, 2016.

Bénassy-Quéré, A.; Giavazzi, F. (eds.) Europe’s Political Spring: Fixing the Eurozone and Beyond, VoxEU eBook, London, CEPR Press, 2017.

Blanchard, O.J.; Leigh, D. "Growth Forecast Errors and Fiscal Multipliers" in American Economic Review, 103, 3, 2013.

Blyth, M. Austerity: The History of a Dangerous Idea, Oxford, Oxford University Press, 2015.

Brunnermeier, M. K., S. Langfield, M. Pagano, R. Rees, S. Van Nieuwerburgh and D. Vayanos, "ESBies: Safety in the tranches", European Systemic Risk Board, Working Paper Series, 21, September 2016.

Cappellin, R., M. Baravelli, M. Bellandi, E. Ciciotti, E. Marelli, "The role of investment and innovation in a program of economic recovery in the EU and in Italy", in Cappellin R., M. Baravelli, M. Bellandi, R. Camagni, S. Capasso, E. Ciccotti, E. Marelli (eds.) Investimenti, innovazione e nuove strategie d'impresa: Quale ruolo per la nuova politica industriale e regionale?, EGEA, Milano, 2017.

European Commission Investment Plan for Europe - State of play, Brussels, 2016.

European Commission, Reflection paper on the Deepening of the Economic and Monetary Union, Brussels, 2017.

Costa Cabral, N.; Gonçalves, J.R; Cunha Rodrigues, N. (eds.) The Euro and the Crisis. Perspectives for the Eurozone as a Monetary and Budgetary Union, Abbildungen in Farbe, Springer, 2017.

De Grauwe, P. “The governance of a fragile Eurozone” in CEPS Working Document, 346, 2011.

De Grauwe, P. “Design Failures in the Eurozone: Can they be fixed?" in LSE 'Europe in Question' Discussion Paper Series, 57, 2013.

De Grauwe, P. "Making the Eurozone Sustainable” in Bénassy-Quéré, A.; Giavazzi, F. (eds.) Europe's Political Spring: Fixing the Eurozone and Beyond, VoxEU eBook, London, CEPR Press, 2017.

De Grauwe, P.; Ji Y. "From Panic-Driven Austerity to Symmetric Macroeconomic Policies in the Eurozone" in Journal of Common Market Studies, 51, S1, 2013. 
De Grauwe, P.; Ji, Y. "How to reboot the Eurozone and ensure its long-term survival", in Baldwin, R.; Giavazzi, F. (eds) How to fix Europe's monetary union: Views of leading economists, VoxEU eBook, London, CEPR Press, 2016.

Della Posta, P. "Structural Divergences, Institutional Fragilities and Foreign Debt in the Euro Area Crisis" in Politica Economica/Journal of Economic Policy, vol. 32, N. 2, pp. 189-222, 2017.

Della Posta P. "Fiscal austerity and monetary easing: which one is to be praised for ending the euro area crisis?, in The European Journal of Comparative Economics, Vol. 15, N. 1, pp. 165-189, 2018a.

Della Posta, P. L'integrazione monetaria in Europa: origini, crisi, istituzioni e teorie economiche, Pisa: Pisa University Press, 2018b.Della Posta, E. Marelli, M. Signorelli, “A market-financed and growth-enhancing investment plan for the euro area", presented at Eaces Conference, Warsaw, 2018.

Della Posta, P. and S. Rehman, "Brexit: Origins and Future Perspectives", in Cabral da Costa, N., J.R. Gonçalves and N. Cunha Rodrigues (eds), After Brexit - Consequences for the European Union, Palgrave Macmillan, 2017, pp. 11-34

ECB, European Central Bank, Unemployment in the Euro area, Speech by Mario Draghi, President of the ECB, Annual central bank symposium in Jackson Hole, 22 Aug 2014.

Eichengreen, B. 'Europe’s Summer Reading List', Project Syndicate, August 10, 2012.

EU, “Four presidents' report: Toward a Genuine Economic and Monetary Union”, Brussels, 26 June 2012.

EU, “Five presidents' report: Completing Europe's Economic and Monetary Union”, Brussels, 22 June 2015.

European Commission, "White Paper on the Future of Europe. Reflections and scenarios for the EU27 by 2025", Brussels, 2017.

European Commission, "Reflection Paper on the Deepening of the Economic and Monetary Unione", Brussels, 2017.

European Commission, Spring Forecasts, Brussels, 2018.

Eurostat, Smarter, greener, more inclusive? Indicators to support the Europe 2020 strategy, Brussels, 2017.

Fadda, S. and Tridico, P. (eds.), Inequality and Uneven Development in the Post-Crisis World, Routledge, 2017.

Holland, S. Beyond Austerity: Alternatives for a Democratic Europe, Nottingham, Spokesman, 2016.

Krugman, P. "Self-defeating austerity" in The New York Times, The Opinion Pages, The Conscience of a Liberal, July 7, 2010. 
Marelli, E.; Signorelli, M. Europe and the Euro. Integration, Crisis and Policies, London and NewYork, Palgrave/Springer, 2017a.

Marelli, E.; Signorelli, M. "Young People in Crisis Times: Comparative Evidence and Policies" in CESifo Forum, 18, 2, $2017 \mathrm{~b}$.

Marelli, E.; Signorelli, M. "Deepening the Economic and Monetary Union: What the Commission Missed in its Reflection Paper" in LSE European Politics and Policy (EUROPP) blog, 20 June, 2017c.

Micossi, S., "Balance-of-payment adjustment in the Eurozone", in Baldwin, R.; Giavazzi, F. (eds.) How to fix Europe's monetary union: Views of leading economists, VoxEU eBook, London, CEPR Press, 2016.

Minenna, M. (eds) The Incomplete Currency: The Future of the Euro and Solutions for the Eurozone, San Francisco, Wiley, 2016.

Minenna M., "Why ESBies won't solve the euro area's problems”, Financial Times, 25 April 2017.

Pagano, M., "Perché servono gli European safe Bond" in www.lavoce.info, 1 giugno, 2017.

Pisani-Ferry, J. "The Euro Crisis and the New Impossible Trinity" in Bruegel Policy Contribution, $1,2012$.

Rodrik, D., "Populism and the economics of globalization", Journal of International Business Policy, pp. 1-22, 2018-

Stiglitz, J.E. The Euro and its Threat to the Future of Europe, London, Allen Lane, 2016.

Stiglitz, J., "The Globalization of Our Discontent", PS On Point, December 5, 2017, available at: https://www.project-syndicate.org/bigpicture/populist-grains-of-truth. 